\title{
Radar Echo Population of Air-Mass Thunderstorms and Nowcasting of Thunderstorm-Induced Local Heavy Rainfalls Part 1: Statistical Characteristics
}

\author{
AUTHOR(S): \\ Ishihara, Masahito
}

\section{CITATION:}

Ishihara, Masahito. Radar Echo Population of Air-Mass Thunderstorms and Nowcasting of Thunderstorm-Induced Local Heavy Rainfalls Part 1: Statistical Characteristics. Journal of Disaster Research 2013, 8(1): 57-88

ISSUE DATE:

2013-02

URL:

http://hdl.handle.net/2433/173302

\section{RIGHT:}

(C) 2013 Fuji Technology Press Co, . Ltd.; この論文は出版社版でありま せん。引用の際には出版社版をご確認ご利用ください。; This is not the published version. Please cite only the published version. 


\title{
Radar Echo Population of Air-Mass Thunderstorms and Nowcasting of Thunderstorm-Induced Local Heavy Rainfalls Part 1: Statistical Characteristics
}

\author{
Masahito Ishihara \\ Educational Unit for Adaptation to Extreme Weather Conditions and Resilient Society, \\ Center for the Promotion of Interdisciplinary Education and Research, Kyoto University \\ Gokasho, Uji, Kyoto 611-0011, Japan \\ E-mail: ishihara.masahito.7u@kyoto-u.ac.jp
}

A radar echo population of 179 thunderstorms generated in the Tokyo metropolitan area on August 5, 2008, when the Zoshigaya rainstorm occurred in the center of Tokyo, is presented. Analysis was made using three-dimensional radar data from the Japan Meteorological Agency. One third of total convective cells had diameters of less than $3.5 \mathrm{~km}$ and the average diameter was $5.5 \mathrm{~km}$. The mode of lifetimes of cells was from 20 to 40 minutes, and $88 \%$ of cells disappeared within 60 minutes after their initiation. The echo-top height of half of the cells reached $15 \mathrm{~km}$, which was the limit of radar observation. Although the rainfall amount estimated from the radar echo was less than $40 \mathrm{~mm}$ for half of the cells, whereas one third of total cells counted were estimated at more than $60 \mathrm{~mm}$. Vertically integrated liquid water (VIL) ranged from 1.4 to $42.4 \mathrm{kgm}^{-2}$. Maximum VIL was equivalent to $70 \%$ of precipitable water estimated from upper sounding on that day. The speed of cell travel was less than $2 \mathrm{~ms}^{-1}$ in accordance with the weak wind velocities in the lower to middle troposphere. The time from echo initiation to rainfall peak was as short as 10 to 30 minutes for almost all cells. Thunderstorms composing the Zoshigaya rainstorm ranked at the highest class in horizontal size, lifetime and total rainfall amount among 179 thunderstorms. The horizontal size of cells in the thunderstorms was nearly equal to those reported for other areas in the world, whereas the echo top height was higher than in the other cases.

Keywords: thunderstorm, local heavy rainfall, weather radar, statistics, nowcasting

\section{Introduction}

Morphological aspects of air-mass thunderstorm generated in the Tokyo metropolitan area (hereafter, "Tokyo") on a day in the summer season are statistically investigated using three-dimensional reectivity data obtained from the radar network system of the Japan Meteorologi-

1. This paper is translated with revision from the TENKI journal published by the Meteorological Society of Japan.

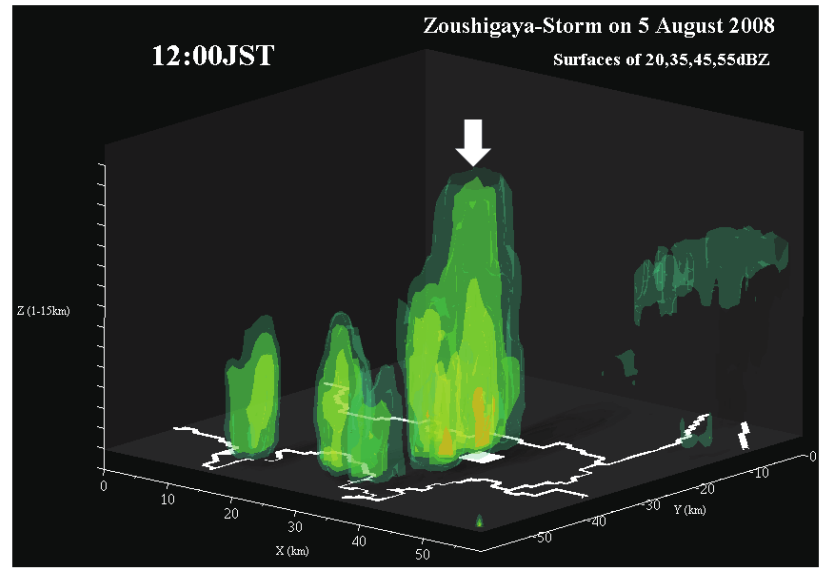

Fig. 1. Perspective view from the southeast sky for the three-dimensional radar echo of thunderstorms (arrows) causing local heavy rainfall in Zoshigaya, Tokyo (squares on the map) on August 5, 2008, created from JMA radar observation data. Iso-surfaces of reectivity of $20,35,45,55 \mathrm{dBZ}$ are shown in the perspective diagram. The height is $1-15 \mathrm{~km}$.

cal Agency (JMA) (Part I). The feasibility of nowcasting local heavy rainfall induced by thunderstorms is studied (Part II). This study begins with local heavy rainfall generated at and around Zoshigaya, Tokyo, before noon on August 5, 2008 (hereafter, the "Zoshigaya rainstorm"), which caused an accident in which 5 workers working at a sewer construction site were swept away and killed due to a ash ood [1]. This was a typical urban ood disaster [2]. According to radar observations by the JMA on August 5, 2008, 179 thunderstorms were generated in the Tokyo metropolitan area from morning to evening of the day. The Zoshigaya rainstorm was induced by two of these thunderstorms (Fig. 1). The study goal of Part I is to determine whether the two were special among the 179 thunderstorms and what the behavior of other thunderstorms was.

In the surface meteorological observations manual by JMA (JMA 2011) [3], thunderstorms are dened as "dense clouds signicantly developed in vertical that appear like mountains or huge towers." In many cases, rainfall disasters such as ooding and landslides are caused by thunderstorms. Thunderstorms also cause windstorms 

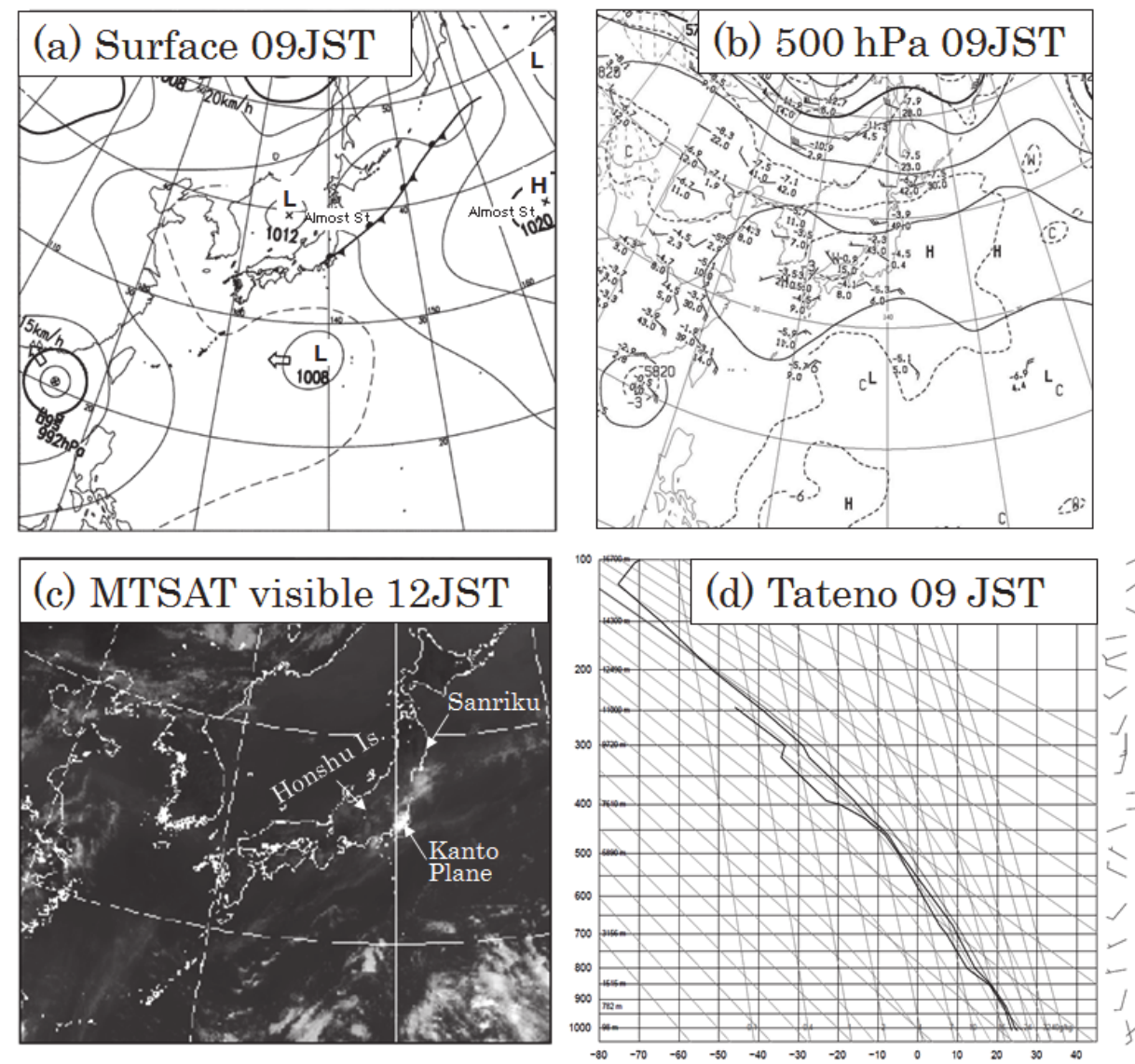

Fig. 2. (a) surface weather chart, (b) Chart at $500 \mathrm{hPa}$, (c) Visible image for Geostationary Meteorological Satellite (MTSAT), (d) Emagram at Tateno (Tsukuba city), on August 5, 2008 ((a)-(c) are provided by the JMA, (d) is cited from the homepage of the University of Wyoming).

such as tornados, downbursts, or gust fronts, as well as lightning damage. The JMA denes heavy rainfall as "rain that may cause a disaster" [4].

Thunderstorms that are not dominated by synopticscale disturbances such as cyclones and occur in a random manner are called "air-mass thunderstorms" or "singlecell thunderstorm" $[5,6]$. Even though they are small on the horizontal scale and have short lifetimes compared to organized convection such as "mesoscale rain systems" [7], they sometimes cause local heavy rainfall and bring about damage. The Zoshigaya rainstorm is a typical case of this in which two thunderstorms with diameters of less than $10 \mathrm{~km}$ caused rainfall of $154 \mathrm{~mm}$ in two hours $[8,9,10,11]$. This phenomenon is called "unstable rainfall" and is monitored with special attention by weather forecasters, but it is difcult to provide heavy rainfall warnings with sufcient lead time, i.e. elapsed time from issuing warning to beginning of heavy rainfall [12]. Many studies on air-mass thunderstorms have been made since the 1940s [5, 13], an understanding of the characteristics of this type of thunderstorms, however, still is lacking and further studies are required in order to issue warnings with an efcient lead time for local heavy rainfall induced by thunderstorms.

In this paper, statistical analysis is presented on the basis of morphology classication using three-dimensional reectivity data (3-D radar data) on a 1-km horizontal and vertical mesh obtained from radar observations [14] every 10 minutes, targeting 179 thunderstorms generated in and around Tokyo on August 5, 2008, when the Zoshigaya rainstorm occurred.

\section{Outline of Environmental Field and Echoes}

On August 5, 2008, there was a traveling anticyclone in the Sea of Japan that almost entirely covered the Japanese Islands, whereas a weak stationary front was analyzed from the coast of Sanriku to the northern part of Kanto (Figs. 2a and c). Winds were weak over Honshu, which was covered with a band-shaped high-pressure zone at $500 \mathrm{hPa}$ (Fig. 2b). According to soundings at 0900 Japan standard time (hereafter "JST") as shown in Fig. 2d, Showalter's index of Tateno in Tsukuba city (about $55 \mathrm{~km}$ to the north-east of Tokyo) was -1.8 , and that of Hachijo Island (about $300 \mathrm{~km}$ south of Tokyo), was 2.8 (not shown). Convective available potential energy (CAPE) was $904 \mathrm{~m}^{2} \mathrm{~s}^{-2}$ at Tateno and $1208 \mathrm{~m}^{2} \mathrm{~s}^{-2}$ at Hachijo Island, making the atmosphere of these areas latently unstable. The difference in wind speeds between the surface and $500 \mathrm{hPa}$ was $5 \mathrm{~ms}^{-1}$ at Tateno and then vertical wind shear wind was small. Whether Tateno or Hachijo 

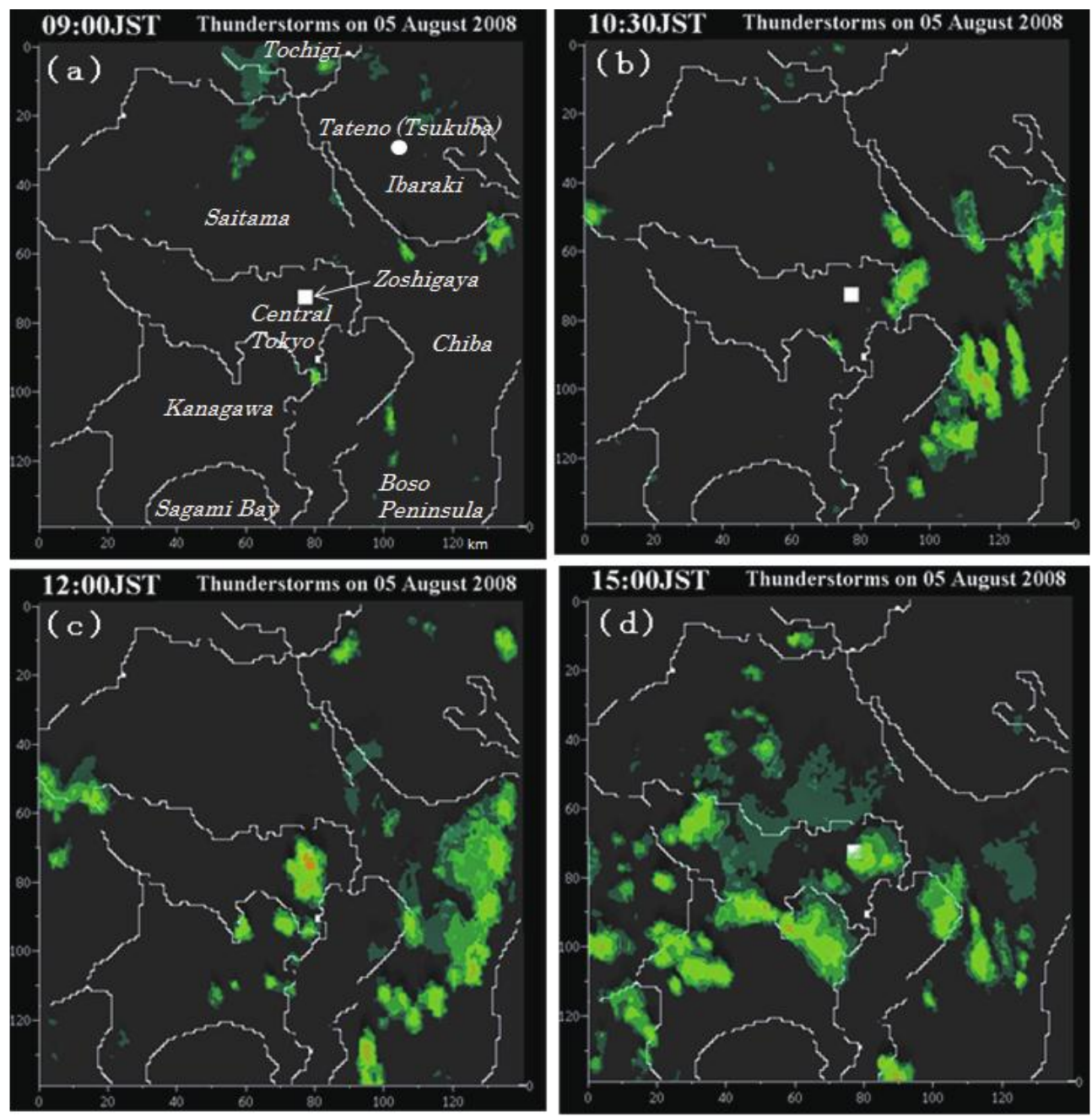

Fig. 3. Radar echoes on August 5, 2008. Perspective viewed from directly above for iso-surfaces of reectivity of 20,30,40,50 dBZ. The white square indicates the position of Zoshigaya, Tokyo.

Island air masses, the air mass over Tokyo was similar to, is not determined, yet in either case, strongly organized convections such as super-cell storms were not likely to be formed in the air mass [15]. The equivalent potential temperature at $950 \mathrm{hPa}$ at Tateno was $353 \mathrm{~K}$, and deep convection reaching the level of neutral buoyancy, $14 \mathrm{~km}$, might be generated, if the air mass at this altitude was forced to rise to a level of free convection, $1.5 \mathrm{~km}$. The altitude of $0^{\circ}$ was $4.9 \mathrm{~km}$.

In this study, the experiment area was dened as a $140 \mathrm{~km}$ square plain including surrounding prefectures centering on Tokyo. Thunderstorms began to be generated in the experiment area at around $0900 \mathrm{JST}$ and were generated and disappeared repeatedly until 1800 JST, peaking in generation at around 1400 JST. The radar echoes generated from 0900 to 1800 JST were investigated here. As indicated by Mura (2009) [8], there were three wind ow systems near the surface above the Kanto region: a southerly wind system from the Boso Peninsula and Sagami Bay, a northerly wind system in Tochigi and Saitama, and a easterly wind system from the Pacic Ocean. This circumstance corresponds to an E-S type wind system typical of this area in summer [16]. Even under the condition of a wind system classied as an E$S$ type, however, organized thunderstorms over $20 \mathrm{~km}$ in horizontal scale may develop as shown in the analyses by Uesugi and Tanaka (2008) [17] and Kawano et al. (2008) [18]. This is presumably due to differences in atmospheric stability, vertical wind shear, and surface friction, and presence or absence of cold outow from thunderstorms, but this is not discussed here.

As seen in the occurrence of radar echoes, thunderstorms began to be generated at around 0900 JST in the north part of Chiba (Fig. 3a) and were almost on a north-south line in mid-northern Chiba due to the convergence of southerly and easterly ows at around 1030 JST (Fig. 3b). From around 1100 JST, southerly and northerly ows converged and thunderstorms were generated centering on Tokyo. After moving northward very slowly, they almost stayed and developed in an area contacting the easterly ow from the Pacic Ocean. Fig. $3 c$ shows the radar echoes generated in Zoshigaya, Tokyo, when heavy rainfall hit the sewer construction site at 1200 JST. The dominant area for thunderstorm generation then moved from Tokyo to north Kanagawa (Fig. 3d). 
Table 1. "Radar index" calculated from 3-D radar data.

\begin{tabular}{|c|c|c|c|}
\hline Radar index & Abbreviation & Definition & Unit \\
\hline Reflectivity & Z & $\begin{array}{l}\text { Radar reflectivity factor } \\
\text { calculated from received signals }\end{array}$ & $\begin{array}{c}\mathrm{dBZ} \\
\left(10 \log \left[\mathrm{mm}^{6} \mathrm{~m}^{-3}\right]\right)\end{array}$ \\
\hline $\begin{array}{l}\text { Vertically integrated } \\
\text { liquid water }\end{array}$ & VIL & $\begin{array}{l}\text { Total amount of liquid water } \\
\text { in a vertical column } \\
\text { (Ice phase and melting layer not } \\
\text { considered) }\end{array}$ & $\mathrm{kgm}^{-2}$ \\
\hline VIL density & VILD & VIL/TOP & $\mathrm{gm}^{3}$ \\
\hline Echo-top height & TOP & $\begin{array}{l}\text { Echo-top height with } \mathrm{Z}=12 \mathrm{dBZ} \\
\text { as a threshold }\end{array}$ & $\mathrm{km}$ \\
\hline
\end{tabular}

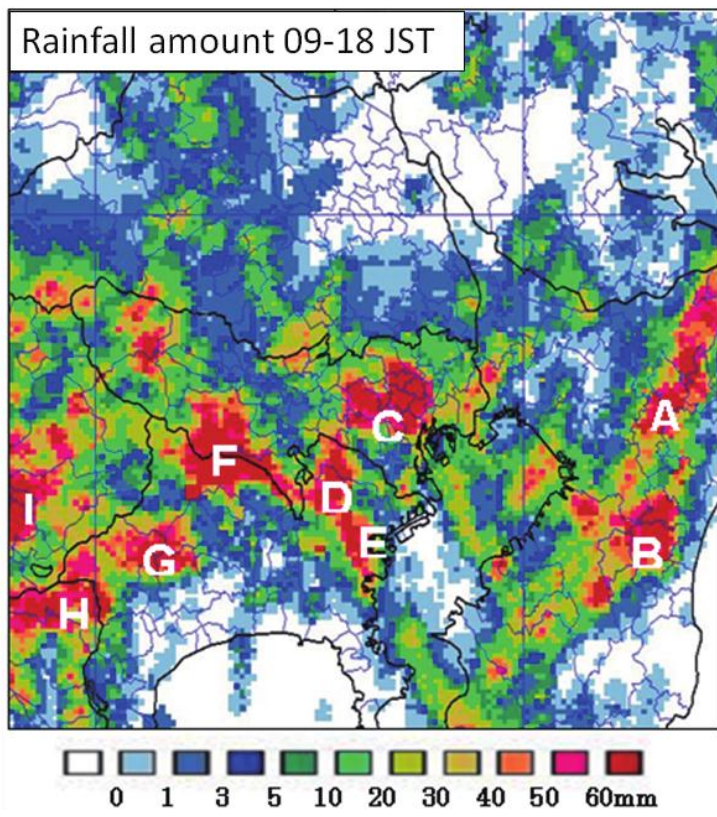

Fig. 4. Integrated rainfall amount from 0900 to 1800 JST on August 5, 2008. A-I are heavy rainfall areas during this period.

\section{Overview of Convection Activities and Anal- ysis Method}

At the rst, the "convective cell" is dened. Ogura et al. (2002) [6] classied thunderstorms generated on the Kanto Plain into three types: air-mass thunderstorms, frontal thunderstorms, and vortex thunderstorms, depending on the trigger of generation. Air-mass thunderstorms are further divided into four subtypes: mountain, mountain to plain, plain, and widespread.

Figure 4 shows the distribution of JMA radarraingauge composite rainfall amount integrated in the analysis period. There are 7 regions, from $A$ to $G$, in which rainfall of $60 \mathrm{~mm}$ or more was recorded. It is possible that the weak stationary front indicated in Fig. $2 \mathrm{a}$ contributed to the generation of convective cells in regions $\mathrm{A}$ and $\mathrm{B}$. These are, however, classied as plain air mass thunderstorms in this study, because there is hardly anything with the nature of a front with this "stationary front" in the temperature eld or wind eld. Convective cells in regions $C, D, E$, and $F$ are plain-type thunderstorms generated on plains or in hills. Heavy rainfall warnings were issued in the analysis period in regions $C, D$, and $E$, which are areas of dense human habitation. Rainfall in region $\mathrm{G}$ is due to mountain air-mass thunderstorms generated over mountains rather than planes. Our analysis covers the 179 convective cells generated on the plains of regions $A-F$, excluding convective cells in region $G$.

Each convective cell was traced from generation to dissipation and numbered serially based on 3-D radar data obtained every 10 minutes. Since radar echoes often occur at an altitude of $2 \mathrm{~km}$ or higher in the generation phase of convective cells, cells were traced referring to the values of reectivity at the $2 \mathrm{~km}$ level $\left(Z_{2 \mathrm{~km}}\right)$ along with vertically integrated liquid water (VIL [19]). A time-series graph of the "radar index" values listed in Table 1 was made from 3-D radar data for each convective cell with 10-minutes increments. Statistical analysis is made in the next section using the time-series graphs as basic data.

\section{Statistical Characteristics of Thunderstorms}

\subsection{Horizontal Size, Lifetime, and Height}

Maximum values of areas with $Z_{2 \mathrm{~km}}$ of greater than $35 \mathrm{dBZ}$ in the lifetime of each convective cell are dened as the "horizontal size," and a histogram of these is shown in Fig. 5. Convective cells smaller than $10 \mathrm{~km}^{2}$ corresponding to circles with a diameter of $3.5 \mathrm{~km}$ account for approximately one third of the total (57). The number gradually decreases as horizontal size increases. The mean is $24 \mathrm{~km}^{2}$ for the same diameter of $5.5 \mathrm{~km}$ and the maximum value is $82 \mathrm{~km}^{2}$ for the same diameter of $10.2 \mathrm{~km}$. Note that relatively small convection is generally dominant.

Figure 6 shows a histogram for the lifetime of each convective cell. The mode (the value that appears most often in a set of data) of the lifetime is between 20 and 40 minutes, and $86 \%$ of all are concentrated below 80 minutes, which means that most thunderstorms were classied into the single-cell type. Mean lifetime was 48 minutes. There were, however, convective cells with 


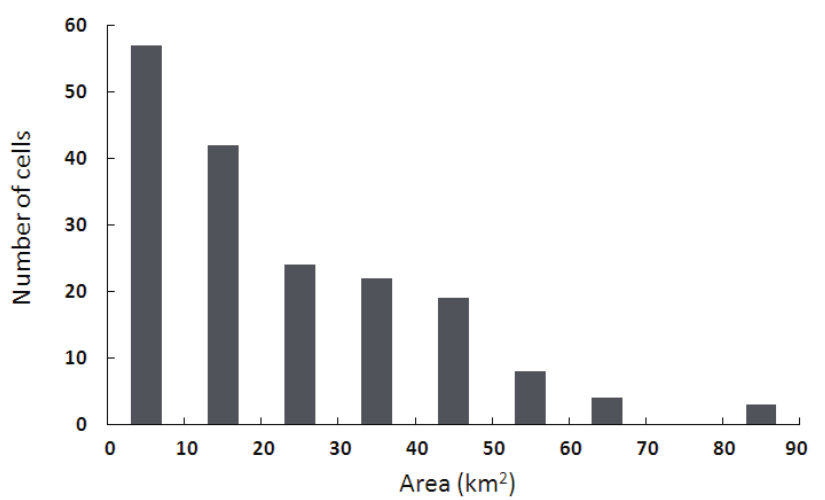

Fig. 5. Histogram of maximum area (horizontal size) in each convective cell.

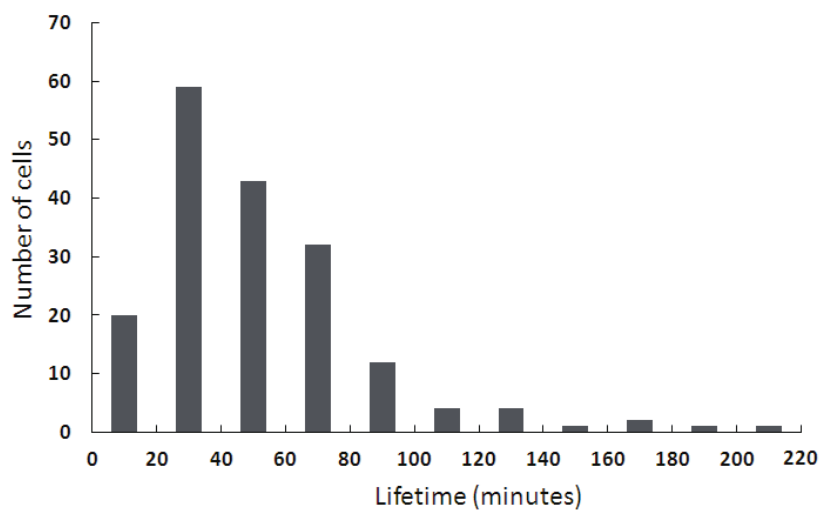

Fig. 6. Histogram of the lifetime in each convective cell.

longer lifetimes, and the lifetime of 13 convective cells reached 120-220 minutes. Although multicell thunderstorms [20] with a longer lifetime were generated, it is likely that the replacement of convective cells in a thunderstorm could not be traced by the radar observation at 10-minute intervals.

Figure 7 shows a histogram of the maximum echo-top height of each convective cell in its lifetime. The number of the echo-top height gradually increased from $4 \mathrm{~km}$ up to $14 \mathrm{~km}$. The most prominent feature of this histogram is that echo-top height exceeded the level of neutral buoyancy of $14 \mathrm{~km}$ in the case of 98 convective cells, $55 \%$ of the total and reached the radar measurement limit of $15 \mathrm{~km}$. Mean echo-top height was $12.3 \mathrm{~km}$. The level of neutral buoyancy of $14 \mathrm{~km}$ is based on the upper sounding in Tateno at 0900 JST (Fig. 2d). The level of neutral buoyancy during the daytime in the analysis period may be higher than the value at 0900 JST considering heating on the surface by solar radiation, an increase in upward sensible heat ux, and the resulting development of the atmospheric boundary layer. It is also likely that some of the thunderstorms exceeded the tropopause of $15.8 \mathrm{~km}$. The nonuniformity of stratication, entrainment of surrounding unsaturated air into the thunderstorms, and the presence of the compensating subsidence of updrafts around thunderstorms are considered as reasons why about half of the convective cells did not reach the level of neutral buoyancy.

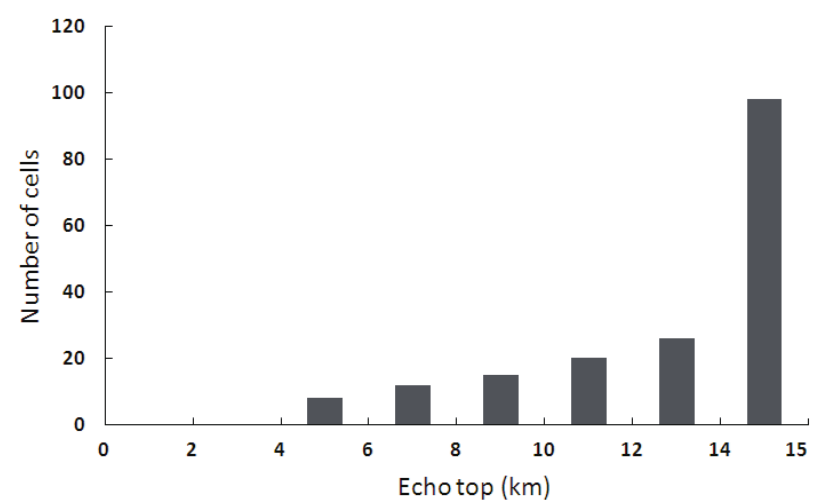

Fig. 7. Histogram of the maximum value of echo-top height in each convective cell.

\subsection{Reflectivity, Rainfall Intensity, and Total Rain-} fall Amount

Figure 8 shows a histogram of the maximum value of $Z_{2 \mathrm{~km}}$ in the lifetime of each convective cell. The maximum values of $Z_{2 \mathrm{~km}}$ for $66 \%$ (119) convective cells of the total exceed $50 \mathrm{dBZ}$ and those for $22 \%$ (41) cells show particularly higher values of $55-60 \mathrm{dBZ}$.

Figure 9 is a histogram of the maximum value of rainfall intensity of each convective cell at an altitude of about $2 \mathrm{~km}$. This rainfall intensity was calculated from reectivity from radar observation at an altitude of about $2 \mathrm{~km}$ by applying the radar calibration method of the JMA [21] using rain gauge data (Appendix A). Convective cells of $67 \%$ (120) of the total temporarily exceeded "very intense rainfall" of $60 \mathrm{~mm} / \mathrm{h}$, and half of the cells (94) indicated "torrential rainfall" of $80 \mathrm{~mm} / \mathrm{h}$ or larger. In addition, especially high rainfall intensity of $180 \mathrm{~mm} / \mathrm{h}$ or more is indicated for 17 convective cells. There is a peak between 200 and $204 \mathrm{~mm} / \mathrm{h}$, because the upper limit of rainfall intensity measurement by radars is xed at $204 \mathrm{~mm} / \mathrm{h}$ by the JMA.

Figure 10 shows a histogram of the total rainfall amount, which was obtained by integrating rainfall intensity values at the $2 \mathrm{~km}$ level at each convective cell over its lifetime. Note here that rainfall intensity values were divided by six, because the radar observation was made 6 times in one hour. The total rainfall amount of 93 convective cells, corresponding to $52 \%$ of the total cells, was less than $40 \mathrm{~mm}$. The next peak is seen between 60 and $80 \mathrm{~mm}$, and the number of cells gradually decreases to $200 \mathrm{~mm}$ with two cells indicating the highest values of 240-280 mm. As seen in Fig. 4, the large amount of rainfall recorded in the area resulted from the fact that active convective cells moved slowly or were almost stationary. Threshold values for issuing heavy rainfall warnings by the JMA are dened in each city and town, and a rainfall amount of $60 \mathrm{~mm}$ per one hour is applied as the threshold in most cities and towns in Tokyo. Fig. 10 shows that 66 $(1 \beta$ of the total) convective cells recorded total a rainfall amount of $60 \mathrm{~mm}$ or greater. Heavy rainfall warnings are issued considering the duration time of rainfall (lifetime of thunderstorms), as is further discussed in Section 4.4. 


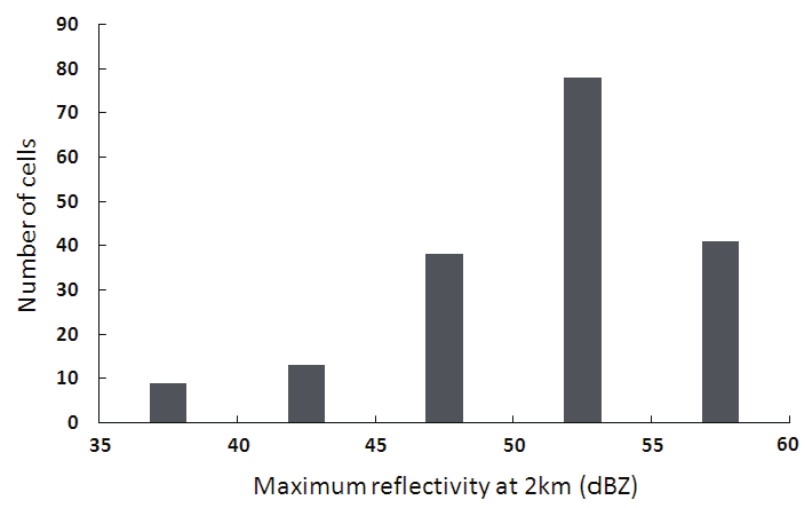

Fig. 8. Histogram of the maximum reectivity at the $2 \mathrm{~km}$ level in each convective cell.

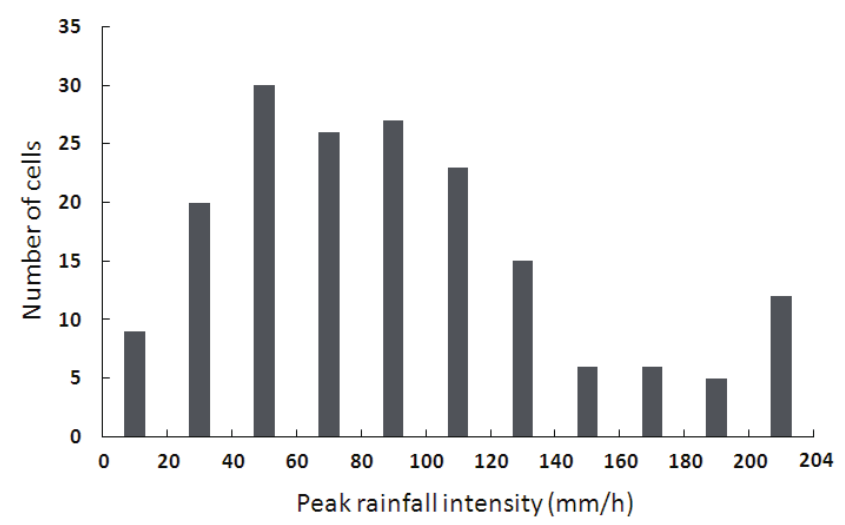

Fig. 9. Histogram of the maximum value of rainfall intensity at the $2 \mathrm{~km}$ level in each convective cell.

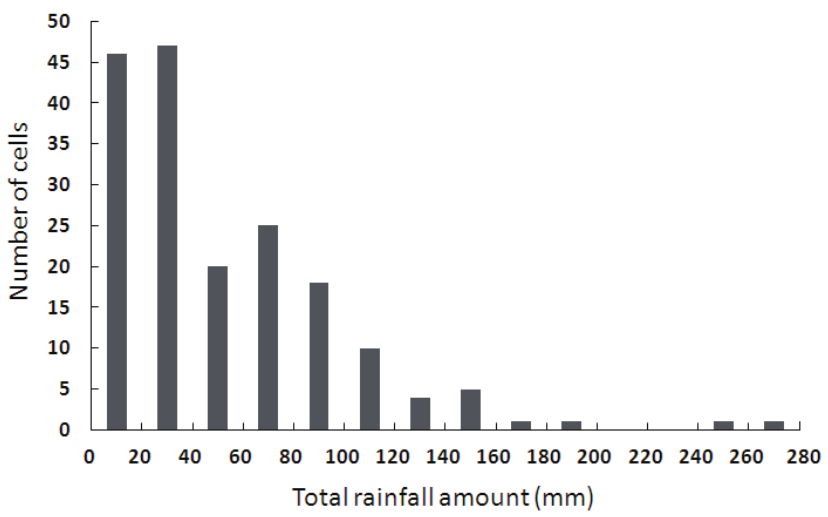

Fig. 10. Histogram of the maximum value of total rainfall amount in each convective cell.

\subsection{Vertically Integrated Liquid Water (VIL)}

Figure 11 shows a histogram of the maximum value of VIL for each convective cell indicated in its lifetime. Values range from 1.4 to $42.4 \mathrm{kgm}^{-2}$ with a mean of $15 \mathrm{kgm}^{-2}$. VIL depends on vertical proles of temperatures and water vapor and the magnitude of vertical motion inside thunderstorms. Precipitable water at Tateno calculated from the sounding in Fig. $2 \mathrm{~d}$ is $65 \mathrm{kgm}^{-2}$, and $43 \mathrm{kgm}^{-2}$ at Hachijo Island. Precipitable water is calculated from proles of temperature and water vapor, but may be changed according to the convergence and diver-

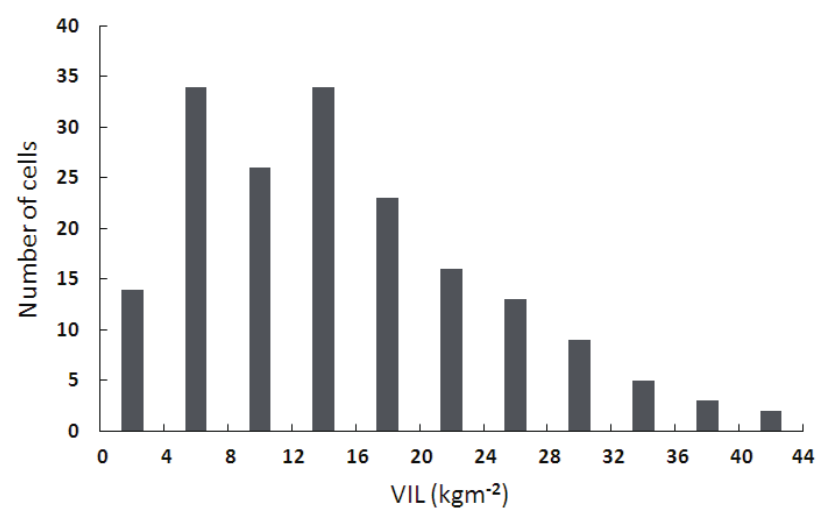

Fig. 11. Histogram of the maximum value of vertically integrated liquid water (VIL) in each convective cell.

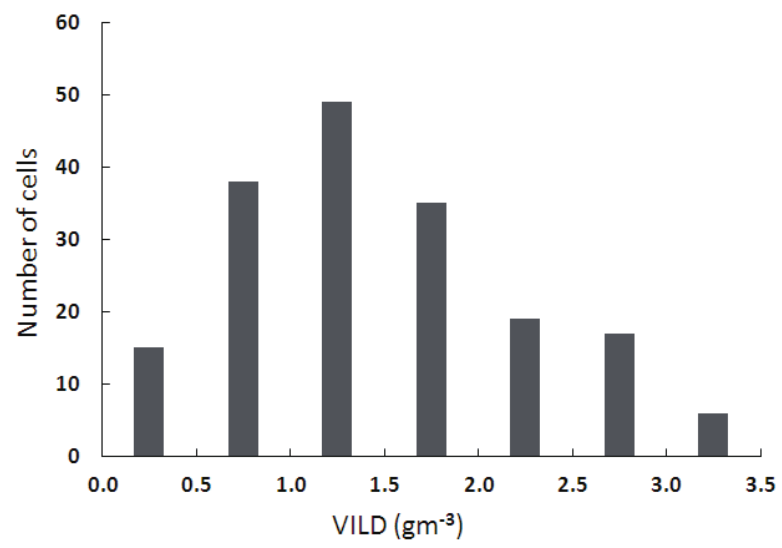

Fig. 12. Histogram of vertically integrated liquid water density (VILD) in each convective cell.

gence of horizontal water vapor ux, while VIL in thunderstorms may uctuate with factors such as horizontal advections of hydrometeor. Precipitable water and VIL are therefore not simply comparable, but the maximum value of VIL in this study does not exceed the precipitable water value calculated from radiosonde observations and seems to be within the appropriate range.

Vertically integrated liquid water density (VILD), obtained by dividing VIL values by echo-top height, can be considered as the mean of rain water content in convective cells. As seen in Fig. 12, VILD ranges from 0.5 to $3.4 \mathrm{gm}^{-3}$ with a peak between 1.0 and $1.5 \mathrm{gm}^{-3}$. Although the physical meaning of VILD have not been discussed much, it is reported that hail with a diameter of $19 \mathrm{~mm}$ falls when the VILD value is $4 \mathrm{gm}^{-3}$ or greater, and that there is almost no hail when the value is smaller than $3.5 \mathrm{gm}^{-3}$ [22]. Uchida et al. (2010) [23] investigated hail events in Japan and proposed an algorithm that hail exists when three conditions are met: VILD is greater than $3.5 \mathrm{gm}^{-3}$; the maximum value of reectivity in a thunderstorm is greater than $55 \mathrm{dBZ}$; and echo-top height is greater than $8 \mathrm{~km}$. There were no convective cells with VILD greater than $3.5 \mathrm{gm}^{-3}$ on August 5 2008. Consequently, it was unlikely that hail was present in thunderstorms generated on the day. 
(a)

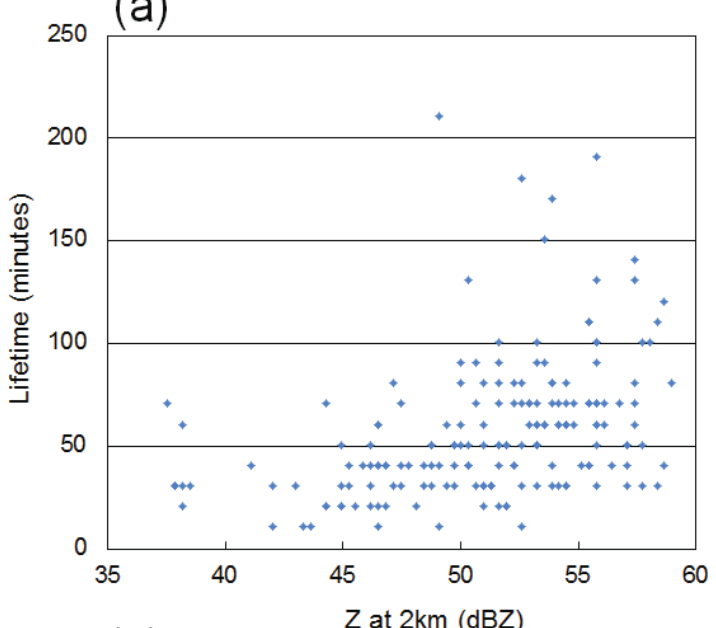

(c)

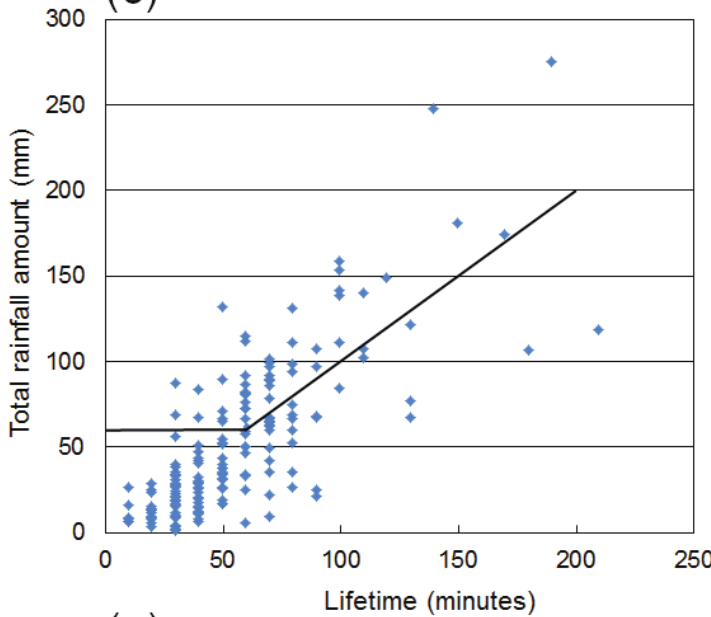

(e)

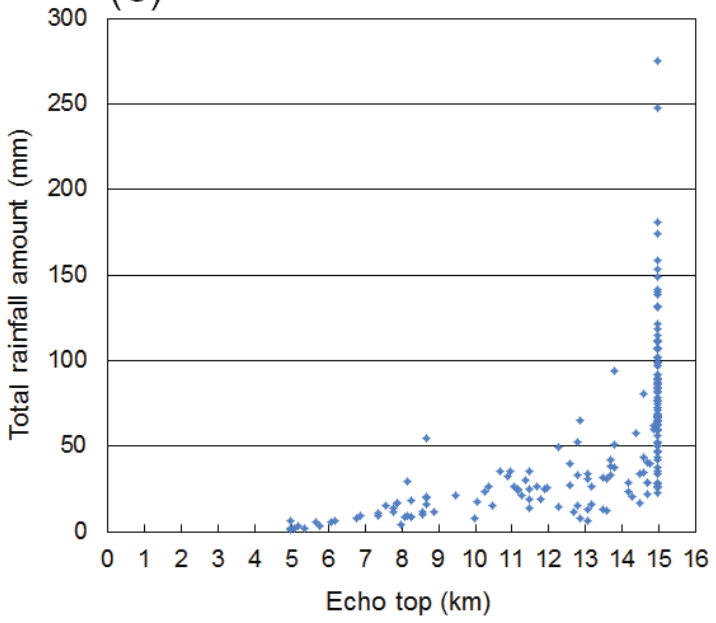

(b)

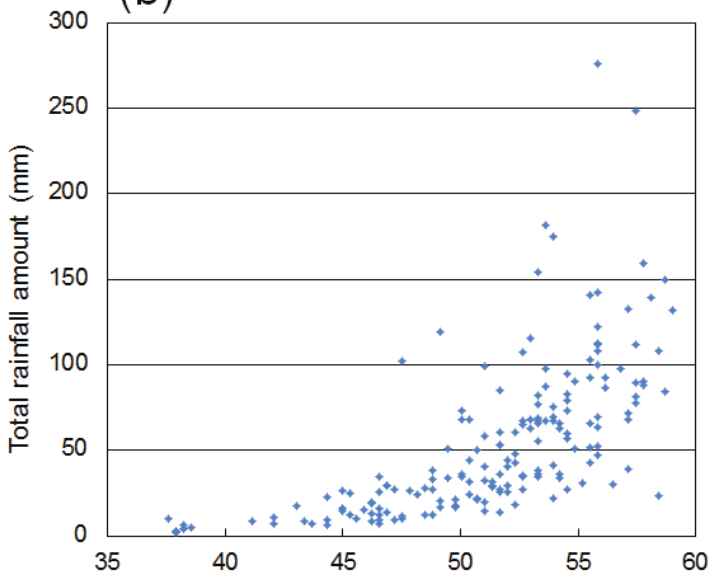

(d)

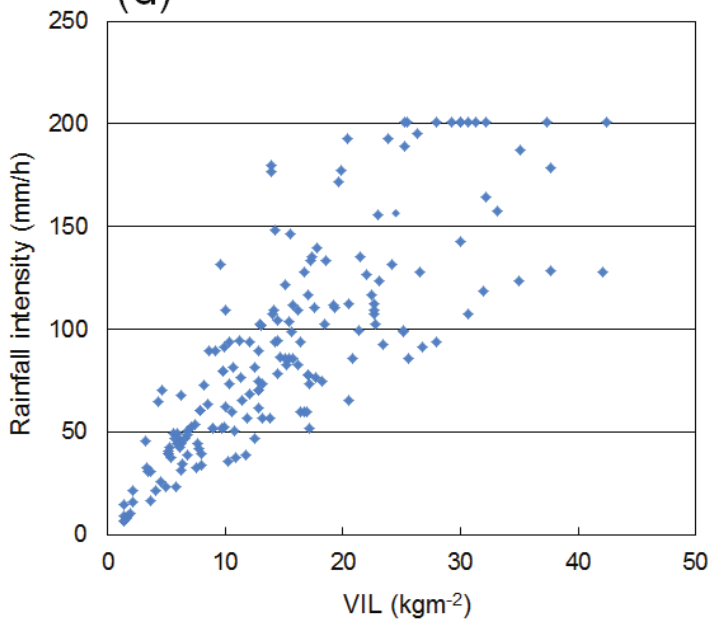

Fig. 13. Scatter diagrams among radar indices. (a) Reectivity at the $2 \mathrm{~km}$ level - lifetime, (b) Reectivity at the $2 \mathrm{~km}$ level - total rainfall amount, (c) Life time - total rainfall amount, (d) VIL - rainfall intensity, (e) Echo-top height - total rainfall amount.

\subsection{Relationship Among Radar Indices}

The relationship among radar indices and individual statistics is examined using the scatter diagrams in Fig. 13. Although there is a tendency that the higher the maximum value of $Z_{2 \mathrm{~km}}$ is, the longer the lifetime of convective cells, a close relationship to one-to-one correspondence cannot be seen between them (Fig. 13a). A positive correlation between $Z_{2 \mathrm{~km}}$ and total rainfall amount can be also seen in Fig. 13b despite large dispersion. Fig. 13c also shows a positive correlation between the lifetime of convective cells and total rainfall amount, but there was a convective cell that caused torrential rain of $130 \mathrm{~mm}$ in a short lifetime of 50 minutes. If none of the convective cells on the day moved and $60 \mathrm{~mm}$ per an hour was se- 
lected as a threshold for heavy rainfall warnings, one third of all convective cells, plotted above the polygonal solid line in Fig. 13c, were objects of heavy rainfall warnings.

Since rainfall intensity is the downward ux of rain water at the bottom of thunderstorms and VIL is the total amount of rain water in thunderstorms, a certain correlation may be expected between rainfall intensity and VIL. Fig. 13d indicates a positive relationship between these values, yet no high relationship is seen. One of the reasons for larger dispersion between the two is thought to be errors in VIL values due to the fact that a xed distribution of raindrop diameter was used in its calculation and the existence of the melting band and ice particles was not considered, and the fact that consideration was not made for the time delay for rain water aloft to reach the bottom of thunderstorms.

Figure $13 \mathrm{e}$ indicates that there is an upper limit of the total rainfall amount at each echo-top height. This corresponds to the fact that the production of rain water in thunderstorms depends on the magnitude of upward motion, and the stronger updraft a thunderstorm has, the taller it is.

\subsection{Movement}

Almost all of the 179 convective cells were generated and disappeared independently and were not organized in lines or other forms. Weak vertical wind shear is considered to be a factor in the situation. Individual convective cells in regions $A$ and $B$ in Fig. 4 moved at a speed of about $2 \mathrm{~ms}^{-1}$ to the north-northeast. Convective cells in regions $C, D$, and $E$ were generated in central Tokyo and north Kanagawa after noon on August 5, 2008, and seemed to move slowly toward the west, but movement resulted from the "propagation" mode in which a new convective cell was generated westward and the existing cell declined and disappeared. A process of "merging" in which two convective cells generated in relatively narrow areas combined into a larger convective cell was also seen.

\subsection{Time from Echo Generation to Rainfall Peak}

In weather forecasting operations, great attention is paid to monitoring thunderstorms from when thunderstorms are recognized until rainfall peaks occur. The time from when convective cells were generated at the $2 \mathrm{~km}$ level until rainfall intensity at the $2 \mathrm{~km}$ level indicated its peak was investigated for 179 individual convective cells. The reason why rainfall intensity at the $2 \mathrm{~km}$ level was used is that the JMA makes radar composite maps from radar data at the $2 \mathrm{~km}$ level. This time has a peak at 10 minutes as shown in Fig. 14a, followed by 20 and 0 minutes. Consequently, rainfall peaks occurred within 30 minutes after the initiation of radar echo for 166 (93\% of the total) convective cells.

When a histogram is made for 66 heavy rainfall convective cells with total rainfall amounts greater than $60 \mathrm{~mm}$ in the same manner as Fig. 14a (Fig. 14b), the peak is also at 10 minutes, followed by 20,30, and 0 minutes. Note that the ratios of 20 and 30 minutes are higher than those
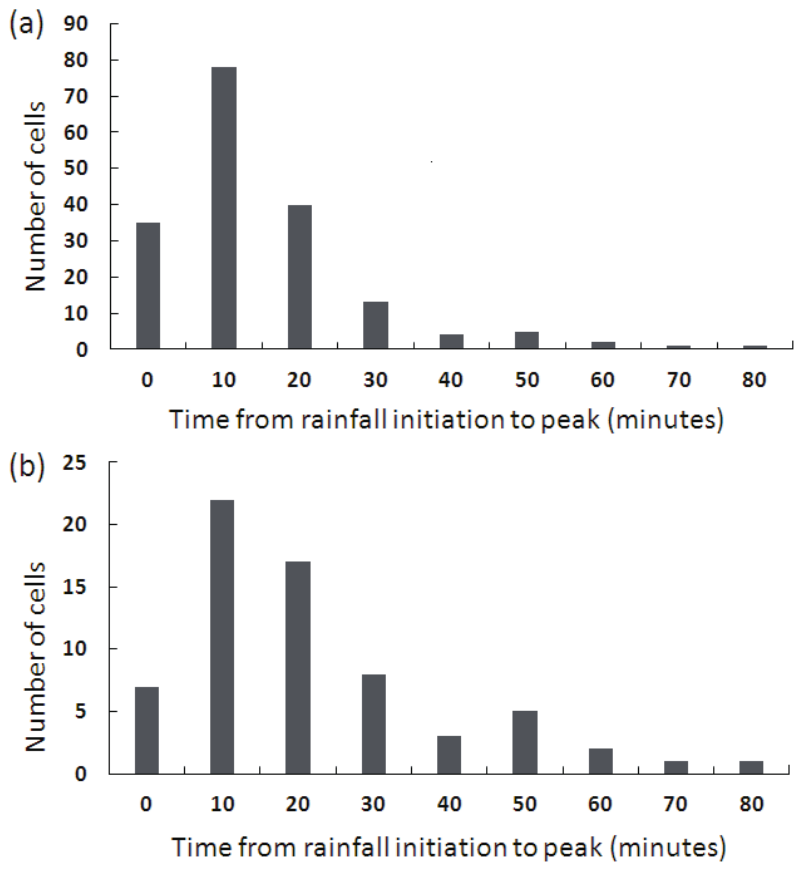

Fig. 14. Histogram of time taken from when convective cells occurred at the $2 \mathrm{~km}$ level until when rainfall at the $2 \mathrm{~km}$ level peaked. (a) 179 convective cells, (b) 66 convective cells with total rainfall amount greater than $60 \mathrm{~mm}$.

in Fig. 14a. In almost all cases, when convective cells were recognized in radar displays, only 20-30 minutes remained for forecasters to make a decision on issuing heavy rainfall warnings, and a rainfall peak occurred on the surface almost simultaneously when convective cells were recognized using radars in the case of $20 \%$ of convective cells. This fact underscores the difculty of issuing heavy rainfall warnings in a timely manner by monitoring thunderstorms using radars, as described in Section 1 [12].

\subsection{Convective Cells that Caused Heavy Rainfall in Zoshigaya}

The rain gauge located near Zoshigaya recorded "torrential rainfall" of $134 \mathrm{~mm}$ in 100 minutes from 1150 to 1330 JST on August 5, 2008, which caused a fatal accident at a sewer construction site in Zoshigaya [1]. A convective cell generated in the southern part of Tokyo at 1100 JST slowly moved northward, then reached Zoshigaya and caused heavy rainfall, merging with another thunderstorm generated ahead of it. To understand whether this convective cell is a particularly developed thunderstorm or not, cumulative histograms for 179 convective cells were created in terms of horizontal size, lifetime, and total rainfall amount, and the order of this convective cell was examined (not shown in gure). The maximum horizontal size of this convective cell was $63 \mathrm{~km}^{2}$ (corresponding diameter of $9 \mathrm{~km}$, cumulative frequency order of $96 \%$ ), the lifetime 110 minutes (the order of $95 \%$ ), and total rainfall amount estimated from radar $175 \mathrm{~mm}$ (the order of $97 \%$ ). It was therefore found that 
Table 2. Statistical values for population of convective precipitation observed by radars in various locations of the world.

\begin{tabular}{|c|c|c|c|c|}
\hline Author & Location & $\begin{array}{c}\text { Horizontal size } \\
\text { (Diameter of } \\
\text { equivalent circle) } \\
(\mathrm{km})\end{array}$ & $\begin{array}{l}\text { Echo-top height } \\
\qquad(\mathrm{km})\end{array}$ & $\begin{array}{l}\text { Lifetime } \\
\text { (minutes) }\end{array}$ \\
\hline Present case & Tokyo & 5.5 & 12.3 & 47.8 \\
\hline Mather (1949) [29] & Massachusetts & 6.2 & 3.2 & \\
\hline Battan (1953) [30] & SW Ohio & 3.6 & & 21.0 \\
\hline Blackmer (1955) [31] & Massachusetts & & & 44.7 \\
\hline Dennis and Fernald (1963) [32] & Eniwetok & 1.8 & & \\
\hline $\operatorname{Battan}(1967)$ [33] & Arizona & & 8.9 & \\
\hline Gerrish (1969) [34] & Miami over water & & 5.7 & \\
\hline Hudlow (1971) [35] & Barbados & 2.3 & & \\
\hline Miller et al. (1975) [36] & NW Dakota & 3.3 & & \\
\hline Lopez (1976) [37] & NW Atlantic & 5.2 & 4.5 & 2.3 \\
\hline Biondini (1976) [38] & Florida & & & 32.3 \\
\hline Houze and Cheng (1977) [39] & Atlantic tropics (GATE) & 4.4 & 4.1 & \\
\hline Ishihara (1985) [40] & $\begin{array}{l}\text { Equatorial western Pacific } \\
\text { (MONEX) }\end{array}$ & & 2.9 & \\
\hline Dixon (1994) [41] & Colorado & 6.4 & 8.8 & \\
\hline DeMott and Rutledge (1998) [42] & West Pacific (TOGA COARE) & & 5.4 & \\
\hline Potts et al. (2000) [25] & Sydney & 7.3 & 5.3 & \\
\hline
\end{tabular}

the convective cell that caused the heavy rainfall at Zoshigaya was ranked at the highest position among 179 convective cells in all three aspects: horizontal size, lifetime, and total rainfall amount.

\subsection{Comparison with Other Cases}

The targets of this study are 179 thunderstorms that were generated in and around the Tokyo metropolitan area in a summer day. The number of days on which air-mass thunderstorms occurred (air-mass thunderstorm days) in Tokyo from 1999 to 2010 was investigated. Airmass thunderstorms were generated on 132 days of the 12 years. The average was 11 days in a year with a large uctuation. Occurrences of scattered thunderstorms with small horizontal size as in the present case are found on 1-10 days a year with an average of 5 days. In 2008, air-mass thunderstorms of this type were generated on 10 days, occurring most often during the 12 years. This indicates that August 5, 2008 was one of those typical days on which unorganized small air-mass thunderstorms were generated.

Since there is no preceding study on this kind of radar statistics in Japan, results of this study will be compared with overseas studies. Table 2 combines data collected by Lopez (1977) [24] and Potts et al. (2000) [25]. Values in the table are calculated again as geometric mean rather than arithmetic mean using original data in order to avoid error due to outlier data. The generation and development of thunderstorms are affected by various factors such as atmospheric stratication, vertical wind shear, and landforms, but individual mean values are simply compared in terms of horizontal size, echo-top height, and lifetime without considering these factors.

Horizontal sizes, as shown by equivalent circle diameters in Table 2, ranged from $1.8 \mathrm{~km}$ to $7.3 \mathrm{~km}$ in 10 cases, and $5.5 \mathrm{~km}$ of the present case is, almost the mean value among them. No regional characteristics are found in horizontal size. A statistical analysis made by Potts et al. (2000) [25] for thunderstorms around Sydney, Australia in the summer season denes "thunderstorms" using a reectivity threshold of $30 \mathrm{dBZ}$, obtaining a mean of $7.3 \mathrm{~km}$ in the horizontal size. When the threshold value is reduced to $30 \mathrm{dBZ}$ from $35 \mathrm{dBZ}$ in this study, the horizontal size in this study is increased by about $30 \%$ and the mean becomes $6.4 \mathrm{~km}$, being closer to the value of Potts et al. (2000) [25].

Regarding echo-top height, the mean of this study, $12.3 \mathrm{~km}$, is particularly high compared to other cases. It may not make much sense, however, to compare it with cases in other regions, since echo-top height of convection strongly depends on thermal stratication. Potts et al. (2000) [25] obtained the value of $5.3 \mathrm{~km}$ by setting the threshold for echo-top height as $30 \mathrm{dBZ}$. A larger echotop height would be expected in their study if the threshold value is set to $12 \mathrm{dBZ}$ as in the present case. The present case of lifetime shows the longest value in 5 cases in which the lifetime of convections was investigated in Table 2. 


\section{Conclusions}

There were 179 thunderstorms (convective cells) generated in and around Tokyo in the 9 hours of daytime on August 5, 2008, when local heavy rainfall occurred in Zoshigaya, Tokyo. The Morphological aspects of these convective cells as seen by the JMA radar network are summarized as follows:

The maximum horizontal size of each convective cell in its lifetime was less than $10 \mathrm{~km}^{2}$ (diameter of the equivalent circle: $3.5 \mathrm{~km}$ ) in one third of all cells, with a mean of $24 \mathrm{~km}^{2}$ (diameter: $5.5 \mathrm{~km}$ ) and a maximum of $82 \mathrm{~km}^{2}$ (diameter: $10.2 \mathrm{~km}$ ).

The mode of lifetime of convective cells was between 20 and 40 minutes, and $86 \%$ of the total existed less than 80 minutes. The mean lifetime was 48 minutes, whereas 13 convective cells having long lifetimes between 120 and 220 minutes.

The echo-top height for half of all convective cells reached $15 \mathrm{~km}$, which was the measurement limit of radar observation. This is a value $1 \mathrm{~km}$ higher than the level of neutral buoyancy, $14 \mathrm{~km}$, calculated from the sounding at Tateno.

Concerning the maximum value of rainfall intensity from each convective cell, $67 \%$ of convective cells showed "very intense rainfall" larger than $60 \mathrm{~mm} / \mathrm{h}$, and half of the total cells gave "torrential rainfall" greater than $80 \mathrm{~mm} / \mathrm{h}$.

The maximum value of total rainfall amount from each convective cell was less than $40 \mathrm{~mm}$ for about half of cells, and $60 \mathrm{~mm}$ or more for one third of the total.

VIL ranged from 1.4 to $42.4 \mathrm{kgm}^{-2}$ with a mean of $15 \mathrm{kgm}^{-2}$. The maximum VIL was about $70 \%$ of precipitable water calculated from upper sounding observation.

A combination of 2 indices for each convective cell, i.e., maximum reectivity intensity at the $2 \mathrm{~km}$ level and lifetime, shows a positive correlation with large dispersion.

Convective cells moved as slowly as $2 \mathrm{~ms}^{-1}$ because wind was weak in the middle lower troposphere. Some convective cells appeared to move due to the mode of propagation in which a new convective cell was generated near a preexisting cell.

The time from when thunderstorms were recognized by the radar system until rainfall peaked was 1030 minutes in almost all cases. This caused the difculty in issuing heavy rainfall warnings in a timely manner when thunderstorms were monitored using radars.
The convective cell that caused the Zoshigaya rainstorm was of the highest rank of the 179 thunderstorms in all aspects: horizontal size, lifetime, and total rainfall amount.

As a result of a comparison with similar statistical analysis results overseas, the horizontal size of this study was equivalent to overseas results, whereas echo-top height and lifetime were larger.

Morphological aspects of thunderstorms generated in and around Tokyo on a summer day were understood based on the present research. Part II [26] discusses methods for monitoring of thunderstorm behavior using radars and issuing heavy rainfall warnings more rapidly and more precisely for local heavy rainfall caused by thunderstorms using the analysis results obtained in this study as basic data. These results may also be used as a basic background for thunderstorms by forecasters and for the verication of numerical forecasts, particularly for mesoensemble numerical modelings [27].

\section{Acknowledgements}

3-D radar data used in this study was provided by the Observations Department of the JMA. Mr. Hiroshi Miyagi of the Forecast Department of the JMA kindly provided detailed information on 3-D radar data. The author wishes to thank Mr. Toshihiro Sato of the Observations Department and Mr. Shogo Edamoto (now at the Wakayama Local Meteorological Observatory) for creating a program for tracing convective cells semi-automatically and extracting data in specic regions from archive data; Dr. Yasutaka Makihara of JMA for advice on Appendix A; and Dr. Fumiaki Fujibe of the Meteorological Research Institute of the JMA and Dr. Kosaku Mogi of the Japan Agency for Marine-Earth Science Technology and two peer reviewers for their in valuable advice. This research was made as a study in the research project "Tokyo Metropolitan Area Convection Study for Extreme Weather Resilient Cities 2000-2004" supported by the Strategic Funds for the Promotion of Science and Technology of the Japanese Ministry of Education, Culture, Sports, Science and Technology.

\section{References:}

[1] Bureau of Sewerage, Tokyo Metropolitan Government, "Report on the accident of the reconstruction of the Zoshigaya sewerage main line," p. 12, 2008.

[2] M. Maki, “Urban ash ooding," Tenki, Vol.57, pp. 167-169, 2010 (in Japanese).

[3] Japan Meteorological Agency, "Surface Meteorological Observations Manual," pp. 77-83, 2011 (in Japanese).

[4] Japan Meteorological Agency, "Knowledge on weather, terms for weather forecasting and precipitation," Web site of JMA, http://www.jma.go.jp/jma/kishou/know/yougo_hp/kousui.html [accessed Jan. 22, 2013]

[5] H. R. Byers and R. R. Braham Jr., "The Thunderstorms. U. S. Government Printing Ofce," p. 287, 1949.

[6] Y. Ogura, K. Okuda, and A. Taguchi, "The thunderstorm activity observed by SAFIR and its relation to the atmospheric environment over the Kanto Area in the summer. Part I: An overview of the thunderstorm activity and thunderstorm generating mechanisms," Tenki, Vol.49, pp. 541-553, 2002 (in Japanese).

[7] M. Yoshizaki and T. Kato, "Meteorology on Heavy Rainfall and Snowfall," Asakura publishing Co., p. 175, 2007 (in Japanese).

[8] N. Mura, "Case study on local heavy rainfall in Tokyo on August 5,2008 and its numerical experiment using the JMA-NHM model," Tenki, Vol.56, pp. 933-938, 2009 (in Japanese). 
[9] A. Kato and M. Maki, "Localized heavy rainfall near Zoshigaya, Tokyo, Japan on 5 August 2008 observed by X-band polarimetric radar - Preliminary analysis," SOLA, Vol.5, pp. 89-92, 2009.

[10] K. Hirano and M. Maki, "Method of VIL calculation for X-band polarimetric radar and potential of VIL for nowcasting of localized severe rainfall - Case study of the Zoshigaya downpour, 5 August 2008 -," SOLA, Vol.6, pp. 89-92, 2010.

[11] D.-S. Kim, M. Maki, S. Shimizu, and D.-I. Lee, "X-band dualpolarization radar observations of precipitation core development and structure in multi-cellular storm over Zoshigaya, Japan, on August 5, 2008," J. Meteor. Soc. Japan, pp. 685-699, 2012.

[12] A. Okubo, N. Mashiko, N. Sakamaki, M. Nishi, E. Nagata, and T. Takami, "Prediction of convective rain at warm phase in Tokyo area based on the strong rain scenario - Improvement for securing at the "lead time" in issuing warnings and advisories for heavy rain," pp. 41-55, 2007 (in Japanese).

[13] Japan Society for the Promotion of Science, "Research on thunderstorms," Denki-shoin, p. 94, 1950 (in Japanese).

[14] Observations Department, JMA, ity control of radar data and usage of newly developed radar data," Weather Service Bulletin, Japan Meteorological Agency, 76, pp. 1-113, 2009 (in Japanese)

[15] H. B. Bluestein, "Synoptic-Dynamic Meteorology in Midlatitudes. Volume II: Observations and Theory of Weather Systems," Oxford Univ. Press, pp. 487-488, 1993.

[16] F. Fujibe, K. Sakagami, K. Chubachi, and K. Yamashita, "Surface wind patterns in Tokyo in the preceding afternoon short-time heavy rainfall of midsummer days," Tenki, Vol.9, pp. 395-405, 2002 (in Japanese).

[17] T. Uesugi and Y. Tanaka, "Occurrence structure of shorttime heavy rainfall in the center of Tokyo on 4 July 2000," Tenki, Vol.55, pp. 23-36, 2008 (in Japanese).

[18] S. Kawano, H. Ichikawa, and H. Hayashi, "Analysis of a thunderstorm causing short-term heavy rainfall in the western Tokyo on August, 15, 2005," Tenki, Vol.55, pp. 832-836, 2008 (in Japanese).

[19] D. R. Greene and R. A. Clark, "Vertically integrated liquid water A new analysis tool," Mon. Wea. Rev., Vol.100, pp. 548-552, 1972.

[20] K. A. Browning, "The structure and mechanisms of hailstorms," Meteor. Monogr., Vol.16, No.38, pp. 1-43. 1977.

[21] Y. Makihara, "Algorithms for precipitation nowcasting focused on detailed analysis using radar and raingauge dat," Tech. Rep. Meteorological Research Institute, Vol.39, pp. 63-111, 2000, Available from the following web-site: http://www.mrijma.go.jp/Publish/Technical/DATA/VOL_ 39/39_063.pdf [accessed Jan. 22, 2013]

[22] S. A. Amburn and P. L. Wolf, "VIL density as a hail indicator," Wea, Forecasting, Vol.12, pp. 473-478, 1997.

[23] K. Uchida, S. Mizomoto, A. Sawada, and M. Ishihara, "Study on monitoring hail using weather radars," Tenki, Vol.57, pp. 646-650, 2010 (in Japanese).

[24] R. E. Lopez, "Lognormal distribution and cumulus cloud populations," Mon. Wea. Rev., Vol.105, pp. 865-872, 1977.

[25] R. J. Potts, T. D. Keenan, and P. T. May, "Radar characteristics of storms in the Sydney area." Mon. Wea. Rev., Vol.128, pp. 3308$3319,2000$.

[26] M. Ishihara, "Radar echo population of air-mass thunderstorms and nowcasting of thunderstorm-induced local heavy rainfalls Part II: a feasibility study on nowcasting," J. Disaster Research, Vol.8, No.1, pp. 69-80, 2013 (this number).

[27] K. Saito, M. Kunii, M. Hara, H. Seko, T. Hara, M. Yamaguchi, T. Miyoshi, and W.-K. Wong, "WWRP Beijing Olympic 2008 forecast demonstaration/ research and development project (B08FDP/RDP)," Tech. Rep. Meteorological Research Institute, Vol.62, pp. 1-210, 2010 , Available from the following web-site: http://www.mrijma.go.jp/Publish/Technical/DATA/VOL_62/tec_rep_mri_62_1.pdf [accessed Jan. 22, 2013]

[28] J. S. Marshall and W. M. Palmer, "The distribution of raindrops with size," J. Meteor., Vol.5, pp. 165-166, 1948.

[29] J. R. Mather, "An investigation of the dimensions of precipitation echoes by radar," Bull. Amer. Meteor. Soc., Vol.30, pp. 271-277, 1949.

[30] L. J. Battan, "Duration of convective radar cloud units," Bull. Amer. Meteor. Soc., Vol.34, pp. 227-228, 1953.

[31] R. H. Blackmer Jr., "The lifetime of small precipitation echoes," Proceedings 5th Weather Radar Conf., Asbury Park, NJ, Amer. Meteor. Soc., pp. 103-108, 1955.

[32] A. S. Dennis and F. G. Fernald, "Frequency distributions of shower sizes," J. Appl. Meteor., Vol.2, pp. 767-769, 1963

[33] L. J. Battan, "Silver lodide Seeding and Radar Echoes from Convective Clouds," Institute of Atmospheric Physics Sci. Rep. No.23, The Univ. of Arizona, p. 11, 1967.
[34] H. P. Gerrish "Mesoscale studies of instability patterns and winds in the tropics," Radar Meteorological Laboratory, Institute of Marine and Atmospheric Sciences, University of Miami, p. 77, 1969.

[35] M. D. Hudlow "Three dimensional model of precipitation echoes for X-band radar data collected during BOMEX," Bomex Bulletin No.10, BOMAP Ofce, NOAA, pp. 51-63, 1971.

[36] J.R. Miller Jr. A. S. Dennis, J. H. Hirsch, and D. E. Cain "Statistics of shower echoes in western North Dakota," Preprints 16th Radar Meteor. Conf., Houston, Tex., Amer. Meteor. Soc. pp. 391-396, 1975.

[37] R. E. Lopez, "Radar characteristics of the cloud populations of tropical disturbances in the northwest Atlantic," Mon. Wea. Rev. Vol.104, pp. 268-283, 1976.

[38] R. Biondini, "Cloud motion and rainfall statistics," J. Appl. Meteor. Vol.15, pp. 205-224, 1976.

[39] R. A. Houze Jr. and C.-P. Cheng, "Radar characteristics of tropical convection observed during GATE: Mean properties and trends over the summer season," Mon. Wea. Rev., Vol.105, pp. 964-979, 1977.

[40] M. Ishihara, "Statistical analysis of radar echoes observed in the equatorial western Pacic during summer MONEX in 1979," J. Meteor. Soc. Japan, Vol.63, pp. 210-225, 1985

[41] M. J. Dixon, "Automated storm identication, tracking and forecasting - A radar-based method," Cooperative Thesis, Vol.148, National Center for Atmospheric Research, p. 181, 1994.

[42] C. A. DeMott and S. A. Rutledge, "The vertical structure of TOGA COARE convection. Part I: Radar echo distributions," J. Atmos. Sci., Vol.55, p. 2730-2747, 1998.

\section{Appendix A. Outline of "Algorithms for Pre- cipitation Nowcasting Focused on Detailed Analysis Using Radar and Raingauge Data" by Makihara (2000)}

First, values of reectivity $(Z)$ at the $2 \mathrm{~km}$ level obtained from radar observations are converted to rainfall intensity $(R)$ using the $Z-R$ relational expression $(Z=$ $200 R^{1.6}$ ) of Marshall and Palmer (1948). Next, the rst correction coefcient is obtained by comparing mean rainfall intensity in an hour calculated from radar data over the observation region and the mean rainfall amount integrated in an hour using the AMEDAS rain gauges in the radar coverage. Temporary rainfall amount values for each $1-\mathrm{km}$ mesh are determined considering the correction of the passing height of radar beams over the meshes.

The second correction coefcient is calculated by comparing the temporary rainfall amount and rain gauge value in meshes in which rain gauges are collocated. The third coefcient for each 1-km mesh is determined from second correction coefcients in a $50-\mathrm{km}$ square using weighted interpolation. Fig. 9 in the main text shows values of rainfall intensity obtained by correction applying the third correction coefcient to rainfall intensity from radar observations each 10 minutes. Note that the rst to third correction coefcients above are terms used for the convenience of explanation here only. 